\title{
Recognising Indigenous Land: Analysing the Success of Native Title and Land Rights Campaigns
}

\author{
Rosalin Kuriype \\ University of Technology Sydney, Faculty of Arts and Social Sciences, PO Box 123, Ultimo NSW \\ 2017, Australia. rosalin.kuriype@student.uts.edu.au
}

DOI: https://doi.org/10.5130/nesais.v4i1.1529

\begin{abstract}
Historically, the Indigenous struggle for land rights has been contingent upon the interventions and negotiations of the government. However, the past displacement engendered by colonisation has made proving continuous connection to land difficult, thus rendering native title a frequently problematic avenue towards recognition. This essay argues that grassroots land rights campaigns have had more tangible successes, visible through the physical acquisition of land rather than symbolic 'recognition'.
\end{abstract}

Keywords: Mabo decision; native title; land rights; activism

\section{Introduction}

As Norman has attested (2015), the centrality of land rights to advancing Aboriginal issues is widely held, but has, as this paper will convey, been historically contingent upon the interventions and negotiations of the government. Despite this, an examination of Indigenous land ownership in Australia reveals the varied levels of success achieved through land rights campaigns and native title. In determining which of the two have proven to be more effective, such success will be demonstrated when 'recognition' goes beyond acknowledgement and is visible through a physical acquisition of land. This paper will explore the differing social and political motivations behind land rights and native title legislation, exploring campaigns as early as the 1920s, which built momentum in the $1960 \mathrm{~s}$ and continue to take effect into the present day.

\section{Judicial Action vs. Social and Political Activism}

Although both native title and land rights campaigns are responses to the offences of colonisation and dispossession of Indigenous land, there are an array of distinctions, as put forward by scholars Kelly and Behrendt (2007). Distinguishing between the two avenues towards Indigenous ownership of land, the scholars collectively equate land rights legislation with the strong social and political activism that 
evolved in the 1960 s to 1980 s and included both conservative and radical Indigenous and nonIndigenous peoples. While having evolved from such a political movement, it is in contrast to that of native title, a legal regime enacted by the courts following its judicial recognition in Mabo (No2) of 1992.

Notwithstanding, the legislation enabled a governmental mechanism to channel similar claims of native title that would inevitably arise from Mabo (2007). However, Calma (2005) asserts the importance of land rights legislation in recognising Indigenous structures of law within the Australian legal system and the historic injustices of colonial legal processes. Having originated from the land rights movements, such legislation exemplifies the resounding impact land rights campaigns have had in returning prior Indigenous land to its traditional owners. In extension of this, Foley and Anderson discuss their issues pertaining to native title, describing it as a "weak form of title to some communities, but the 'extinguishment' of claims for the vast majority" (2006, p. 83). As Indigenous activists, the two authors note their retracement from commonplace typology of associating native title with land rights, and express the significance of the land rights movement to reinforcing Aboriginal voices (Foley \& Anderson 2006, p. 83). While the successes and failures of native title claims will be addressed later in this paper, it is pertinent to understand its position and origin within a historically activist-driven movement.

\section{The Australian Aboriginal Progressive Association (AAPA)}

Despite a majority of scholars asserting the Indigenous land rights movement as becoming prominent in the 1960s, this paper advocates the notions put forward by Goodall and Maynard, who address the significance of the AAPA in the 1920s. Founded by Fred Maynard, the politically motivated organisation was a public voice for the dissatisfaction of Indigenous peoples, whose protests against their loss of lands was publicised to the media and the rest of Australia, in particular NSW (Maynard 2005). Inspired by the growing international protests evolving from African American demonstrations, the AAPA repeatedly insisted on the Aboriginal peoples' connection to Australian land, addressing their prior rights to the country before colonisation (Goodall 1995). Although the AAPA were not as successful in reclaiming land as they were in ending child removal practices (Goodall 1995), their documented impact as the first Aboriginal political movement is illustrative of their role in initiating future land rights campaigns.

\section{The 1960 and 1970s}

The beginning of the 1960s saw the issue of land rights once again become prominent in the political discourse of states and territories (McGregor 2009). This was particularly prevalent during the 1963 land claims of the Yolngu of Yirrkala in Arnhem Land. Following the approval of mining leases in the area, the Yolngu peoples demonstrated a profound resistance, declaring their traditional interests to the land for tens of thousands of years before British 'settlement' (Mansfield 2017). Despite acknowledging the validity of the claims made in the Yirrkala Bark Petitions, the movement had ultimately failed and is one example of when land rights campaigns have been unsuccessful. 
Irrespective of this, the significance of these claims to Parliament cannot go unnoticed, having been "the first recognition of Indigenous Land claims in Australian structures" (Mansfield 2017, p. 4).

The Wave Hill Walk Off is demonstrative of a much more triumphant land rights campaign, with Vincent Lingiari leading his fellow Gurindji workers in protest of the inequality shown between themselves and the white stockmen. Lasting several years, the campaign eventually resulted in the Whitlam Government granting the Gurindji People a considerable portion of Wave Hill Station, which was situated on Gurindji land itself (Mansfield 2017). This recognition of prior Indigenous land ownership is but one example of protest proving to be an effective tool, especially within the era of the Whitlam Government. The Tent Embassy was also a demonstration initiated in NSW, which inspired Aboriginal communities all around Australia to increase pressure on the upcoming Whitlam government for more concession on land rights (Goodall 1995). Still present in Canberra today, the Tent Embassy, as argued by Foley and Anderson, "became a focal point for the land rights movement" (2006, p. 90). Unlike native title, which focuses on unwanted or unclaimed land, this continuing land rights campaign centres on the return or compensation of ancestral land that has been stolen (Foley \& Anderson 2006).

The effects of this campaign can be seen through the Aboriginal Land Rights (Northern Territory) Act 1976 (Cth), which granted traditional Aboriginal landowners with perpetual ownership over unalientated Crown land in the Northern Territory (Mansfield 2017). This Act, introduced by the Whitlam Government but passed by the Fraser Government, proved instrumental in the procurement of prior Indigenous land, with almost $50 \%$ of Northern Territory land being transferred to the applicable Aboriginal communities (Mansfield 2017). Although such an attainment exemplifies recognition of prior Indigenous land ownership, it was evident during this time that in order to enact change in state land laws, state governments rather than the Federal Government would need to be targeted. This instilled momentum for state-by-state campaigns, which were paramount in securing connections between land ownership rights to Indigenous culture and ensuring Indigeneity was factored into title deeds (McGregor 2009). The Black Defence Group in NSW were one such organisation to instigate grassroots support around Aboriginal land goals (Cook \& Goodall 2013). As Cook describes in his paper with Goodall, "without the Black Defence Group organising that 1977 Land Rights Conference, you might have gone another five or ten years without anything happening" (2013, p. 179). This is especially true, with the Conference having increased communications within rural areas and amalgamated a collective census on common political land strategies and goals (Cook \& Goodall 2013).

Deliberating further on the solidarity of kinship that was developed during the beginnings of the land rights campaigns, Cook (2013) believes this was important in acquiring the recognition and ownership of prior Indigenous lands in NSW today.

You know, communities, they've got land. They would never ever been able to afford the land they got... [and] I think there's a lot more to be gained from the land rights struggle in NSW. (Cook 2013, p. 205)

It is important to note here that although Cook's comments are exemplary of his own experiences in NSW, they commensurate those who have struggled to attain the same level of recognition through native title, as will be explored later in this essay. 


\section{The 1980s}

Following the 1977 Land Rights Conference, the political organising body of the NSW Land Council was developed. The council was instrumental in assembling marches, petitions and powerful demonstrations that took land issues to the streets and publicised their cause. One notable street march, held in 1982, was pivotal in escalating the campaign and forcing the government to meet their demands for land rights laws. This was especially necessary considering the re-elected Wran Government were back in power, showing no inclination of advancing the Aboriginal land rights cause (Cook \& Goodall 2013). Cook and Goodall's chapter, covering this era of Indigenous activism, highlights also the "striking innovation" of welcome spaces for Aboriginal people to converse with each other through bush meetings (2013). These meetings would become crucial in stimulating support and widespread conversations surrounding the overarching effects lands rights would have for Aboriginal people on the ground (Cook \& Goodall 2013). The collaboration here between Indigenous peoples was an effective method of exchanging ideas and information, and should be noted for its role in launching future land rights campaigns. Their unification is indicative of self-governance in action, relying on their own history, knowledge and determination to achieve recognition of their rights to ownership of traditional land. As Cook and Goodall affirm, it "made visible the process of... crossgenerational input... which the government could have had access for its 1983 Land Rights Bill - but in which it had failed to take part" (2013, p. 211).

It is necessary to pursue here the historically documented and continued decisions by federal, state and territory governments to evade consultation with Aboriginal peoples but to consistently intervene in Indigenous matters without discussion, as was highlighted in the Yolngu of Yirrkala case. Although governments can be said to have improved in this area in recent years, it is evident that they are guilty of hindering Indigenous self-determination which, if properly executed, would assist in positive progressive action for Aboriginal peoples, especially in respect to prior Indigenous ownership of land. It is thus increasingly more pertinent to campaign as, unlike native title, which relies heavily on a colonial system determining their right to land, campaigning asserts these rights, challenging such a system and focusing not just on Land Rights Acts but in actually attaining land back, as has been the case during the 1980s. As Cook claims in his chapter with Goodall (2013, p. 231), Aboriginal people "had something that the government couldn't break... there was too much support... from white people as well!" Furthermore, although Land Rights Acts have enabled Indigenous peoples to acquire land, these acts are the fruition of state and territory land rights campaigns throughout the decades. As Norman asserts, "Aboriginal activists saw themselves as contributing to the drafting of the land laws, and are indeed credited with shaping much of the content" $(2015$, p. 52). This exemplifies the manner in which Indigenous Australians have successfully achieved recognition of prior Indigenous ownership of land themselves, more so through land rights campaigns than through native title, as the following sections will address.

\section{The Mabo Decision and Native Title}

On June 3rd 1992, the High Court ruled in favour of the extinguishment of terra nullius, following the successful claim by Eddie Mabo for the Meriam peoples' rights to the Murray Island. For the first time, Australian courts accepted traditional Indigenous laws and customs as being a justification for 
land ownership. By 1993 the Native Title Act was implemented, which gave premise to recognising Indigenous titles to land. In order to be successful of this claim, sufficient proof from the time of 'settlement' should be presented; demonstrating how traditional laws and customs have continued to be practiced into the present day, by a consistent Indigenous community, without suspension (Mansfield 2017). These native title rights also extend over areas of sea, following the Commonwealth of Australia v Yarmirr (Mansfield 2017). Although the native title decision gave momentum for land rights to be recognised on a national basis, Laing (2007) asserts the fact that native title does not 'give land' but rather relies on Indigenous groups proving that their traditional links to the area have survived. In Kelly and Behrendt's reading, the authors suggest how this does not equate to the way 'land rights' are known in NSW, because rather than being a political recognition, it is merely "dressing up judicial recognition" (2007, p. 76). It is also noteworthy that even this form of recognition is the result of a lands right campaign, despite being produced within the courts. Irrespective of the aforementioned statements, it is within reason to suggest that native title has allowed for some form of recognition of prior Indigenous landownership. This is evident through the successful claims that have passed and will be addressed in this next section.

\section{Native Title: Success and Obstacles}

Mansfield's article articulates the many successes and challenges associated with native title. The 25 years since the commencement of the Native Title Act had seen 395 determinations recognising the existence of native title, gaining increasing impetus subsequently after the 2009 amendments to the Act (Mansfield 2017). As well as reflecting changing community and government attitudes, the Act has determined all claims from the far west and above Port Augusta in South Australia (Mansfield 2017). Although native title has thus allowed for some recognition of prior Indigenous land to its traditional owners and is steadily proving to be more useful, further data reflects how limited this recognition has been. Norman (2017), whose insights into Aboriginal activism is extensive, reveals in her educational paper for UTS that of the 51 native title determinations in NSW, only eight have successfully claimed the existence of native title either in part or in full. Furthermore, as Foley and Anderson reiterate, only 37 successful claims of native title were achieved ten years after the Act's actualisation; one in NSW and none at all in SA, Victoria, Tasmania or the ACT (2006).

A significant obstacle preventing Aboriginal people from successfully claiming native title is the increasingly difficult task of offering proof of an inextinguishable connection to their land. What is most discouraging is that this difficulty lies in earlier 20th century colonial deterrence, which prevented Indigenous peoples from continuing their culture, language, and in some cases, forestalled elders in Aboriginal communities from passing on their knowledge and customs to future generations (Mansfield 2017). Calma (2005, p. 37) supports Mansfield's statement, acknowledging how "the test for recognition means that in practice, native title is less likely to be proved in the parts of Australia where dispossession and disruption to Aboriginal culture was most effective." Strelein's (2005, p. 260) comments also fall closely in line with those of Calma and Mansfield, addressing that while courts are recognising Indigenous peoples' rights to land, they are concurrently claiming state power to deprive these rights "without consent or recompense" if in the interests of the government. There is evidently a "hierarchical relationship between Indigenous interests and the interests of others," which leaves Aboriginal people reliant on the amenability and benevolence of the state (Strelein 2005, p. 
265). Land rights campaigns have therefore proven to more effective in achieving recognition of prior ownership of land, as it challenges rather than relies on these government interests.

As a final insight into the obstacles of achieving Indigenous landownership recognition through native title, Foley and Anderson's article will be consulted. The pair reflect on the failure of the Mabo case to fully address the land rights movement and claim that despite the intentions of native title, "effective Aboriginal law was denied" (2006, p. 96). They argue that native title is "irrelevant to over 80 per cent of the Aboriginal population, [and] it legitimises dispossession for the vast majority of Aboriginal people" (Foley \& Anderson 2006, p. 97). The scholars take note of Tasmania, claiming its land handbacks as being achieved through their long-term campaigning rather than through native title (Foley \& Anderson 2006). Lee's statements do much to support this, indicating that Tasmania have had "no successful native title claims or even current applications" and that the strong presence of activism which pervaded postcolonial settlement in Australia was far more successful in "engaging with common law and... successful land returns" (Lee 2017, p. 332 \& 316). As pertinently stated by Foley and Anderson, "Strong Aboriginal voices - if sustained and not diverted into bureaucratic structures — can still make advances in land rights for Aboriginal communities" (2006, p. 106).

\section{Conclusion}

As this paper has attempted to demonstrate, land rights campaigns can be seen to have more effectively achieved recognition of prior Indigenous landownership than that of native title. Although the courts are steadily becoming an active path for entitlement to land, the government's ability to extinguish native title has prevented real change from occurring. This is especially prevalent as previous colonial power has prevented present-day Indigenous people from being able to prove their unfailing connection to land. Contrary to this, land rights campaigns have stemmed from a history of social and political activism, utilising petitions, demonstrations and community collaboration to effectively reclaim land and therefore achieve a more palpable sense of recognition.

\section{References}

Calma, T. 2005, Chapter 1: Background - the original of land rights and barriers to economic development through native title, Native Title Report, Australian Human Rights Commission, Canberra.

Cook, K. and Goodall, H. 2013, Part 3: Land Rights NSW 1980s, in Making Change Happen: Black and white activists talk to Kevin Cook about Aboriginal, Union and Liberation Politics, Published by ANU E Press, The Australian National University, Canberra, pp 175-204/235

Foley, G. \& Anderson, T. 2006, 'Land rights and Aboriginal voices', Australian Journal of Human Rights, vol. 2, no. 1, pp. 83-108. https://doi.org/10.1080/1323238X.2006.11910814 
Goodall, H. 1995, 'New South Wales' in A. McGrath (ed) Contested Ground: Australian Aborigines under the British Crown, St Leonards, NSW: Allen \& Unwin, pp 55-120.

Kelly, L. and Behrendt L. Y. 2007, Creating Conflict: Case Studies in the Tension Between Native Title Claims and Land Rights Claims, Journal of Indigenous Policy, vol. 8, pp. 73-102

Laing, N. 2007, 'Distinguishing native title and land rights: not an easy path to rights or recognition', Journal of Indigenous Policy, no. 8, p.50-72.

Lee, E. 2017, 'Aboriginal cultural heritage protection in Tasmania: the failure of rights; the restorative potential of historical resilience', in McGrath, P. (ed), The right to protect sites: Indigenous heritage management in the era of native title, AIATSIS, Canberra.

Mansfield, J. 2017, Indigenous Lands Right: Australia's response following Mabo - the Present and the Future - speech, 17 August,

$<$ http://www.fedcourt.gov.au/_ data/assets/pdf_file/0020/46127/Mansfield-J-20170817.pdf>

McGregor, R., 2009, 'Another Nation: Aboriginal Activism in the Late 1960s and early 1970s', Australian Historical Studies, vol.40, no.2, September, pp.343-360.

https://doi.org/10.1080/10314610903105217

Norman, H., 2015, Government, Aborigines and Power: the NSW Land Rights Inquiry, Chapter 2 in 'What Do We Want? a political History of Land Rights, Aboriginal Studies Press, Canberra, pp 29-49

Norman, H., 2015, 'The aboriginal land rights act: Politics and the art of the possible' In What Do We Want?: A Political History of Aboriginal Land Rights in New South Wales, Aboriginal Studies Press, Canberra.

Norman, H. 2017, Aboriginal land recovery in New South Wales: Historical legacies and opportunities for change, NSW Aboriginal Affairs, Sydney.

Strelein, L. 2005, 'From Mabo to Yorta Yorta: Native Title Law in Australia', Washington University Journal of Law \& Policy, vol 19. No.1, pp. 225-271.

(c) (1) (C) 2018 by the author(s). This article is distributed under the terms and conditions of the Creative Commons Attribution license (http://creativecommons.org/licenses/by-nd/4.0/). 